\title{
Editorial
}

\section{Cities and Urban Heritage in the Face of a Changing Climate}

\author{
Yasemin Didem Aktas ${ }^{1,2}$ (D) \\ 1 UCL Department of Civil, Environmental and Geomatic Engineering (CEGE), London WC1E 6BT, UK; \\ y.aktas@ucl.ac.uk \\ 2 UK Centre for Moisture in Buildings (UKCMB), London WC1H 0NN, UK
}

Citation: Aktas, Y.D. Cities and Urban Heritage in the Face of a Changing Climate. Atmosphere 2021, 12, 1007. https://doi.org/10.3390/ atmos12081007

Received: 13 July 2021

Accepted: 31 July 2021

Published: 5 August 2021

Publisher's Note: MDPI stays neutral with regard to jurisdictional claims in published maps and institutional affiliations.
Urbanisation is defined as the process where ever more people leave rural areas to live in cities. Currently more than $55 \%$ of the world population is estimated to live in cities [1] and despite the current downward trend in urbanisation rates, the UN projections are that the urban population by 2050 will be around $68 \%$ [2]. While the definition of where the rural ceases and urban starts is a matter of lively scholarly debate, by its rough meaning as "dense, built-up, 'man-made' areas" [3], cities are where risks and vulnerabilities concentrate: the large and ever-increasing urban populations require large and complex networks and infrastructures, whose partial or complete failure may quickly exacerbate risk under a given scenario of isolated and cascading disasters [4]. When coupled with other issues especially prominent in urban areas, including deep social and economic inequalities/exclusions, high energy demands, compactness and inaccessibility, both slow and fast onset hazards can have more intense and widespread consequences, making urban resilience an extremely complex and hard-to-achieve goal.

Climate-induced hazards are complex in their formation and progression. Despite our best efforts as researchers to better understand, model and forecast climatic hazards to estimate risks, cities worldwide are under the interacting and compound attack of excessive heating, air pollution, droughts, floods, storms, and so on. These threats undermine infrastructure, and endangers communities of very significant sizes. This impact is magnified in conjunction with their geographic, technical, socio-economic and political context, and through dynamic interdependencies between components of urban systems, especially when urbanisation is too rapid, poor or unplanned.

Along with the rest of the urban infrastructure, urban heritage is also under attack from various intensifying climatic stressors. The influence of changing temperature and humidity cycles, precipitation regimes and wind patterns coalesces with constant transformation of the cityscapes to redefine climate-induced hazards in urban areas. Urban here should be considered as a "lens", magnifying, reducing or otherwise distorting the impact of climatic variables on the built environment and beyond (see Table 1 for a brief overview for some potential ways this lens works). 
Table 1. A brief summary of the main climatic variables affected by global climate change, typical urban contributors affecting the impact of a given climatic variable, the resulting hazard, and some direct impacts of these on heritage fabrics. The arrows indicate how each listed urban contributor will typically affect a given climatic variable (second column) and the trends leading to each hazard (third column).

\begin{tabular}{|c|c|c|c|}
\hline $\begin{array}{l}\text { Climatic } \\
\text { Variables }\end{array}$ & Typical Urban Contributor & Hazard & Some Direct Impacts on Heritage Fabrics \\
\hline Temperature & $\begin{array}{l}\text { Increased anthropogenic heating } \\
\text { (e.g., traffic and } \\
\text { buildings-induced), reduced } \\
\text { evapotranspiration }(\uparrow) \\
\text { Higher thermal admittance } \\
\text { materials, air pollution, urban } \\
\text { morphology }(\uparrow / \downarrow)\end{array}$ & $\begin{array}{l}\text { Urban heat island } \\
\text { (UHI) }(\uparrow) \\
\text { Urban cool island }(\downarrow)\end{array}$ & $\begin{array}{l}\text { Impact on strength and stiffness of the fabric } \\
\text { through varied daily/seasonal temperature } \\
\text { fluctuations; material and integrity loss due to } \\
\text { cracking, spalling and similar weathering; } \\
\text { impact on the (de)sorptive characteristics of the } \\
\text { building materials }\end{array}$ \\
\hline Humidity & $\begin{array}{l}\text { Increased anthropogenic moisture } \\
\text { generation }(\uparrow) \\
\text { Reduced evapotranspiration, } \\
\text { land-use changes leading to } \\
\text { increased surface runoff over } \\
\text { impermeable surfaces }(\downarrow)\end{array}$ & $\begin{array}{l}\text { Urban moisture } \\
\text { island (UMI) }(\uparrow) \\
\text { Urban dry island }(\downarrow)\end{array}$ & $\begin{array}{l}\text { Impact on strength and stiffness of the fabric } \\
\text { through varied daily/seasonal humidity } \\
\text { fluctuations; corrosion, biodeterioration, and } \\
\text { biological attack, leading to material decay and } \\
\text { loss }\end{array}$ \\
\hline \multirow[t]{3}{*}{ Precipitation } & \multirow{3}{*}{$\begin{array}{l}\text { Suitable aeresols, and high urban } \\
\text { temperatures encouraging cloud } \\
\text { formation }(\uparrow) \\
\text { Reduced evapotranspiration }(\downarrow)\end{array}$} & $\begin{array}{l}\text { Soil saturation, } \\
\text { flooding }(\uparrow)\end{array}$ & $\begin{array}{l}\text { Corrosion, biodeterioration, efflorescence, } \\
\text { leading to material decay and loss; moisture } \\
\text { enrichment within the fabric, hence } \\
\text { moisture-induced decay of building materials; } \\
\text { mould growth in-wall/indoors; rising damp }\end{array}$ \\
\hline & & Drought $(\downarrow)$ & $\begin{array}{l}\text { Differential settlement related structural } \\
\text { problems, or foundation damage }\end{array}$ \\
\hline & & $\begin{array}{l}\text { Wind-driven rain }(\uparrow) \\
\text { Storms }(\uparrow)\end{array}$ & $\begin{array}{l}\text { Moisture enrichment within the fabric, which } \\
\text { may lead to moisture-induced decay of building } \\
\text { materials and mould growth in-wall/indoors; } \\
\text { mechanical forcing on the structural system }\end{array}$ \\
\hline \multirow[t]{2}{*}{ Wind } & \multirow{2}{*}{$\begin{array}{l}\text { Urban morphology including } \\
\text { surface roughness and geometry of } \\
\text { street canyons in relation to } \\
\text { prevalent wind direction }(\uparrow / \downarrow) \\
\text { Thermal influences }(\uparrow / \downarrow)\end{array}$} & $\begin{array}{l}\text { High winds; storm } \\
\text { surges in coastal } \\
\text { areas }(\uparrow)\end{array}$ & $\begin{array}{l}\text { Surface erosion; additional mechanical forcing } \\
\text { on the structural system; in case of storm surges, } \\
\text { flooding }\end{array}$ \\
\hline & & Stagnation episodes $(\downarrow)$ & $\begin{array}{l}\text { Exacerbation of the impact of UHI, UMI and air } \\
\text { pollution }\end{array}$ \\
\hline
\end{tabular}

\section{Is It All Doom and Gloom?}

No. In stark juxtaposition to all this, cities are also where an immense potential to physically, culturally, and politically mitigate the impact of climate change exists. The innovation potential of cities, if harnessed through new forms of institutional organisations and governance, can help greatly to sustainability and climate resiliency efforts [5]. While the role and responsibilities of local governments around the world on climate mitigation and adaptation can be diverse depending on the overall organisational hierarchies within countries and the relevant legislation, they nonetheless have immense powers to address many issues locally and directly, and often in liaison and collaboration with other stakeholders. This includes non-governmental and non-profit organisations, academia and the private sector. Cities are hubs for developing, experimenting with and implementing low energy solutions for climate-induced hazards and the relevant socio-economic drivers behind cities' vulnerability in the face of these. This opens up new avenues for co-creating integrated responses to challenges for climate resilience and creates a hopeful alternative to the dystopian views of cities' futures under climate change [6]. 


\section{This Special Issue}

The collection of the papers in this Special Issue gives a broad cross-section of diverse problems facing urban heritage under the impact of a changing climate, and the methods and tools that can be used to address these. Urban heritage studies with specific emphasis on climatic impact require a highly crossdisciplinary outlook, bringing together not only a multitude of scientific and technological disciplines but also public engagement and policy, and urban and heritage theory, among others, as evidenced here.

Sardella et al. [7], in their comprehensive, pan-European study, discuss the methodology employed for a web-based GIS tool for the visualisation and analysis of the vulnerabilities of cultural heritage under current and different future climate scenarios. To this end, the authors undertake a thorough review of global and regional climate models to identify regional climate projections at different resolutions to map the climatic hazards in central and Mediterranean Europe. The tool is available at https:/ /www.protecht2save-wgt.eu/, accessed on 13 July 2021. Brimblecombe et al.'s study [8] is another contribution focussing on risk-mapping: highlighting the benefits of such mapping to inform the management plans by the custodians of heritage, they map the risk of extreme temperatures, flooding, earthquake, fire, and sediment disasters (debris flow, slope failure and landslides) for Tokyo. Drawing on inspirational artwork and historic photography, the authors discuss the trends in the frequency and intensity of individual hazards/climatic parameters.

Ulu and Durmus Arsan [9] aim to identify the energy performance baseline for 22 historic and contemporary heritage buildings in Basmane District in Izmir, Turkey, and explore retrofit options to improve the performance through a methodology integrating an on-site survey, building performance modelling and a retrofit impact assessment. The authors highlight the importance of case-by-case approach in developing the retrofit solutions for future use of heritage buildings, while ensuring their energy efficiency.

The paper by Aktas et al. [10] looks into the role that building stocks play in shaping urban microclimates. To this end, the authors report their findings from monitoring multiple land-use areas in Kuala Lumpur, including a heritage site at the heart of the city centre, Kampung Baru, composed of vernacular Malay homes. The paper then discusses the outdoor thermal comfort and energy use potential in diverse urban settings. The paper also touches upon the risks associated with the reconceptualization of heritage to achieve certain political and economic goals. Carroll and Aarrevaara [11] further expand on the relations between climatic impact on heritage buildings and urban planning through a questionnaire activity aimed at probing the planning professionals' perceptions and experiences of the phenomenon. In the specific case of Finland, the authors note a good level of understanding and appreciation of climatic risks by town planners; however, they conclude that they cannot always prioritise heritage structures when tackling such risks.

Fouseki et al. [12] tackles the important question of how the residents of heritage homes make decisions around energy efficiency, thermal comfort and conservation through 59 semi-structured interviews in Greece, Mexico and the UK. With a system dynamics approach, the authors identify one-directional and iterative relationships between features, perceptions of and responses to these, demonstrating that heritage conservation is a socially and culturally dynamic practice. Noticing some strong differences in different countries and in urban-rural environments, the authors highlight that the policies should account for the unique nature of each context, and that only by doing so can they support the energy efficiency and climate resiliency of heritage.

Orr and Cassar [13] focus on wind-driven rain (WDR) indices. The authors aim to develop a new index able to better express "shorter, more intense and more consistent WDR events" than the existing semi-empirical indices, and further expand on urban complexity and seasonality, among others. Importantly, they also adopt the frequency of occurrence of gutter overspill to extend it the use of their developed index to a risk/impact indicator.

The issue includes two review contributions: Basu et al. [14] provides an extensive review of decay mechanisms of stones, lime mortar and bricks that are expected to be exacerbated under the climatic trends for the UK. The paper also includes a comprehensive 
section on the methods which can be employed for decay monitoring of building stones, making it a complete, geologically focussed reference resource for climatic impact on urban stone-built heritage. Jahed et al. [15] offers a critical review of the UK and Turkey's energy retrofitting policy frameworks aimed at built heritage. To this end, the paper makes a chronological, multisectoral analysis of regulatory and financial schemes as well as the outcomes of voluntary programmes and competitions to identify the incentives and constraints which shape the overall energy retrofitting realm in these countries.

Last but not the least, the issue also has an opinion piece: Pender and Lemieux's exceptionally insightful paper [16] encourages a paradigm shift in our way of addressing indoor thermal comfort through "layered systems". The authors provoke the reader to re-examine design and assessment principles where heat loss by radiation is the main player, rather than air temperature, to be able to fight back against the commodification of comfort through HVAC systems, which are only counterproductive for the sustainability endeavour. Touching upon so many key topics, from professional education/training to vernacular design principles, this paper aims to innovate our understanding as to how heritage structures can contribute to achieving climate resiliency.

I hope the research community will find this Special Issue of interest.

Funding: This research received no external funding.

Conflicts of Interest: The author declares no conflict of interest.

\section{References}

1. The World Bank. Urban Population (\% of total Population). Retrieved from The World Bank—Data. Available online: https: / / data.worldbank.org/indicator/SP.URB.TOTL.IN.ZS (accessed on 13 July 2021).

2. United Nations. World Urbanization Prospects: The 2018 Revision. United Nations, 2018. Available online: https:/ / population. un.org/wup/ (accessed on 13 July 2021).

3. Harding, A.; Blockland, T. Urban Theory: A Critical Introduction to Power, Cities and Urbanism in the 21st Century; SAGE: London, UK, 2014.

4. Hunt, J.C.; Aktas, Y.D.; Mahalox, A.; Moustaoui, M.; Salamanca, F.; Georgescu, M. Climate change and growing megacities: Hazards and vulnerability. Eng. Sustain. 2018, 171, 314-326. [CrossRef]

5. Leichenko, R. Climate change and urban resilience. Curr. Opin. Environ. Sustain. 2011, 3, 164-168. [CrossRef]

6. Bulkeley, H. Cities and Climate Change; Routledge: London, UK, 2013.

7. Sardella, A.; Palazzi, E.; von Hardenberg, J.; del Grande, C.; de Nuntiis, P.; Sabbioni, C.; Bonazza, A. Risk Mapping for the Sustainable Protection of Cultural Heritage in Extreme Changing Environments. Atmosphere 2020, 11, 700. [CrossRef]

8. Brimblecombe, P.; Hayashi, M.; Futagami, Y. Mapping Climate Change, Natural Hazards and Tokyo's Built Heritage. Atmosphere 2020, 11, 680. [CrossRef]

9. Ulu, M.; Durmus Arsan, Z. Retrofit Strategies for Energy Efficiency of Historic Urban Fabric in Mediterranean Climate. Atmosphere 2020, 11, 742. [CrossRef]

10. Aktas, Y.D.; Wang, K.; Zhou, Y.; Othman, M.; Stocker, J.; Jackson, M.; Hood, C.; Carruthers, D.; Latif, M.T.; D’Ayala, D.; et al. Outdoor thermal comfort and building energy use potential in different land use areas in tropical cities: Case of Kuala Lumpur. Atmosphere 2020, 11, 652. [CrossRef]

11. Carroll, P.; Aarrevaara, E. The Awareness of and Input into Cultural Heritage Preservation by Urban Planners and Other Municipal Actors in Light of Climate Change. Atmosphere 2021, 12, 726. [CrossRef]

12. Fouseki, K.; Newton, D.; Murillo Camacho, K.S.; Nandi, S.; Koukou, T. Energy Efficiency, Thermal Comfort, and Heritage Conservation in Residential Historic Buildings as Dynamic and Systemic Socio-Cultural Practices. Atmosphere 2020, 11, 604. [CrossRef]

13. Orr, S.A.; Cassar, M. Exposure Indices of Extreme Wind-Driven Rain Events for Built Heritage. Atmosphere 2020, 11, 163. [CrossRef]

14. Basu, S.; Orr, S.A.; Aktas, Y.D. A Geological Perspective on Climate Change and Building Stone Deterioration in London: Implications for Urban Stone-Built Heritage Research and Management. Atmosphere 2020, 11, 788. [CrossRef]

15. Jahed, N.; Aktas, Y.D.; Rickaby, P.; Bilgin Altinoz, A.G. Policy Framework for Energy Retrofitting of Built Heritage: A Critical Comparison of UK and Turkey. Atmosphere 2020, 11, 674. [CrossRef]

16. Pender, R.; Lemieux, D.J. The Road Not Taken: Building Physics, and Returning to First Principles in Sustainable Design. Atmosphere 2020, 11, 620. [CrossRef] 